\title{
Meme Frameworks
}

A Semiotic Perspective on Internet Memes

\author{
Richard Kearney \\ Auckland University of Technology, New Zealand \\ rke@westlake.school.nz
}

\begin{abstract}
Memes are an increasingly prevalent means of communication in online spaces. Their influence is felt in the offline world as attitudes and dispositions traverse the postdigital membrane. The medium is emblematic of the democratic and participatory communities of the internet, yet there is evidence that they play a role in the well-documented political radicalisation that happens in online spaces. Semiotic concepts such as inter and intratextuality, and Peirce's conception of habit provide a framework to understand how the language of memes is developed and transformed across a network.
\end{abstract}

\section{Keywords}

memes - semiotics - participatory culture - postdigital - online radicalisation 


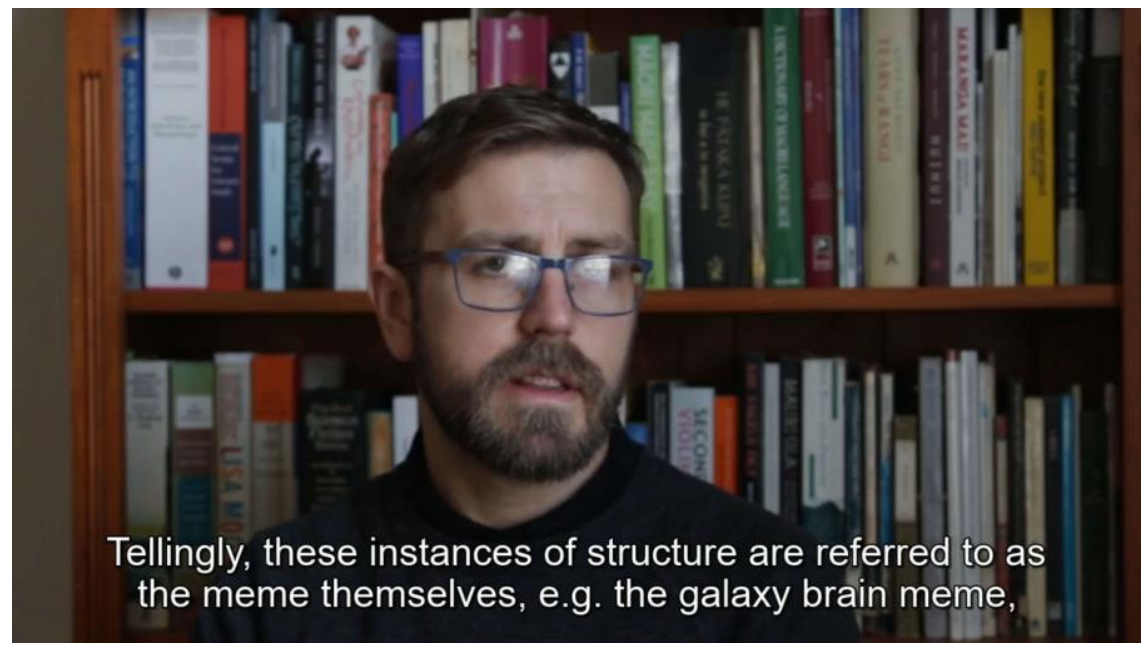

FEATURE Richard Kearney's article is based on the film 'Meme Frameworks' which can be viewed here.

\section{$1 \quad$ Introduction}

In the postdigital landscape young people participate in networked communities and publics daily. It is becoming increasingly commonplace to see memes as one mode, or the primary mode of communication in many of these spaces - spaces as diverse as corporate advertising, media fan communities, and political groups from the mainstream to the fringes. This paper will look at the ways in which memes have become part of the political landscape, in particular their role in radicalisation.

2

The Left Can't Meme / So This is the Right's Fabled Memeing Ability

As the constantly churning feedback cycle of the online social networks produce further stratified communities in visual, creative, and entertainment focused media, so too, political viewpoints become more partisan. In her book, Kill all normies: Online culture wars from 4chan and tumblr to Trump 
and the alt-right, Angela Nagle (2017) says that as New Media increasingly takes over from old media,

gatekeepers of cultural sensibilities and etiquette have been overthrown, notions of popular taste maintained by a small creative class are now perpetually outpaced by viral online content from obscure sources, and culture industry consumers have been replaced by constantly online, instant content producers.

NAGLE, 2017, p. 3

Nagle (2017) cites the Bernie Sanders Dank Meme Stash facebook page and the reddit forum The_Donald as two examples from each side of the American political spectrum that arose during the 2016 election. While these groups are perhaps more visible, communities that work to galvanise political thought are now commonplace. Shit Bootlickers Say and Sassy Socialist Memes are 'leftbook ${ }^{\prime 2}$ pages that boast followers in the six figures. New Zealand has its own political meme pages such as Freshly Picked Green Memes, and David Seymour Memes for Overtaxed Liberal Teens, there's even a rare bipartisan meme group NZ Swing Voters Against Dogmatic Party Affiliated Memes. It is now fairly commonplace to see memes from these groups liked or shared from the online accounts of political figures. Networked publics are the ground for a new generation constructing and reconstructing their political beliefs using the materials they have, as apolitical as those materials may seem at first (Metahaven, 2013).

A paradigmatic example of the infiltration of political discussion by meme culture was Donald Trump Jr. sharing a meme depicting 'the deplorables' (Pelltier-Gagnon \& Diniz, 2018). The meme is a remix of a promo image for 'the untouchables' featuring the faces of Donald Trump's campaign team as well as a cartoon version of Donald Trump as cartoon character 'Pepe the frog'. This image requires a range of intertextual understanding to fully parse. The term 'deplorables' was in response to Hillary Clinton declaring Trump supporters "A basket of deplorables" (Chozick, 2016), and its inclusion is a response in an ironic, devil-may-care tone. The Pepe the frog image is more sinister in nature - originally a character from Matt Furie's cult comic Boy's

Here I use Lev Manovich's exhaustive definition in The Language of New Media (2001).

2 Left-leaning pages on facebook. 
Club (Frank, 2016), Pepe was adopted as a 'reaction image's on online image boards such as 4 chan. ${ }^{4}$ Pepe evolved into a fully blown meme when the peculiar practice of 'collecting' 'rare pepes' emerged on 4chan, which involved content producers remixing images of Pepe for consumers/collectors (Yopak, 2018). When Pepe went mainstream (Pepe memes were shared on instagram by the likes of Katy Perry and Nicki Minaj [Kiberd, 2015]) 4chan users sought to make this practice inaccessible to outsiders. Given that the board's user base, specifically the members of the subforum $/ \mathrm{pol} /{ }^{5}$ are historically far-right leaning, the logical move to prevent 'normies' from sharing Pepe memes was to associate him with the far-right ideology (Pelltier-Gagnon \& Diniz, 2018; Yopak, 2018). And thus, the most widely known meme-as-dog-whistle ${ }^{6}$ was born.

\section{Online Radicalisation: From \#Gamergate to \#88}

It is out of this intersection of community identity and political ideology that online radicalisation emerges. As can be ascertained from the title of this section, I will largely focus on the far-right ideology here. There are two reasons for this. Firstly, it is this ideology that manifests in the real world as violent acts with far more frequency. The vast majority of domestic terror attacks in America in 2018 were carried out by far-right extremists (AntiDefamation League, 2019). The horrific act of terror committed in Christchurch, New Zealand earlier this year was enacted by a white supremacist, whose manifesto was littered with online memes and dogwhistles (Johnson, 2019). Secondly, it is the right who have been more successful in their online messaging, leading to a growing online community

3 Arguably a sub-genre of meme, not addressed in this work. For a good analysis of this phenomena see Are you literally what you post? (Rugnetta, 2015).

4 4chan.org is an online anonymous imageboard, infamous for its antisocial content.

Standing for 'politically incorrect'.

6 A 'dog-whistle' in politics is a coded message that means something to those in the know but seems innocuous to the general consumer. Common examples are the use of the term 'family values' to signal traditional Christian values and rejection of LGBT rights, 'racial self interest' to gesture towards the far-right notion of 'the great replacement' (Novara Media, 2019), or Ronald Reagan's use of the term 'welfare queen' a coded message used to refer to single, black mothers. It allows a degree of plausible deniability for the user, either in outright denial of its meaning, or a plea of ignorance to its true meaning. 
of young followers and an intensification of far-right beliefs. Natalie Wynn, a left aligned Youtuber, says:

[in far-right Youtube politics] that became a whole ecosystem during gamergate, where you had these far-right gaming channels basically, and then political channels emerged around them. It was the language of Youtube, but they were talking about politics. Whereas with leftist content, it was the language of academia, but on Youtube.

NOVARA MEDIA, 2019, 7:15

And not only is this signalling more effective, it is more deliberate in its purpose. In 2017, a user posted on 4chan an instructional post titled 'Operation O-KKK' instructing users to flood their social media channels with references to the 'ok' hand signal as a white power symbol (Brodeur, 2018). The campaign was successful, the symbol now linked with white supremacy, and culminating in the Christchurch shooter flashing the symbol during a preliminary hearing for his crimes. "Beneath the seeming humorous aspect of memes, there is a particular dynamic through which netizens hijack memes and repurpose them to their particular interests" (Pelltier-Gagnon \& Diniz, 2018, p. 2). Wynn agrees, noting that far-right online individuals use "conventions of internet humour as a cloak for their extremism" (Novara Media, 2019, 5:32). This cloaking has a double purpose of signalling to members of the far right community, while remaining obscure to the general public, but also to allow those who call it out or try to engage with it sincerely to be labelled 'hysterical' or 'over-sensitive' to something seemingly innocuous (Nagle, 2017; Novara Media, 2019). It is this purposefulness and canniness with online modes of communication that make the online far right a dangerous movement.

But is there a cause and effect link between hijacked online humour and actual political extremism? Emerican Johnson (2019a; 2019b) thinks there is. In his two-part video essay The PewDiePipeline: how edgy humor leads to violence he asserts that those who share 'edgy' far right memes or use dogwhistle signalling (such as PewDiePie ${ }^{7}$ ) are part of a framework of stochastic

7 PewDiePie (real name Felix Kjellberg) is one of the highest subscribed to YouTubers whose content primarily consists of him playing, and reacting to, video games. He has had multiple controversies involving race, and his popularity on boards such has 4 chan has led to the phrase 'subscribe to PewDiePie' being used as a dog-whistle. The phrase appeared in the Christchurch shooter's manifesto. A recent controversy involved a video in which he 
terrorism. Stochastic terrorism differs from traditional conceptions of terrorism in that it is characterised by random acts of violence, rather than a hierarchical structure in which a controlling authority has direct contact with the perpetrator. It is a reimagination of the notion of the 'Lone Wolf terrorist, a single deranged individual acting alone, in which the responsibility for the act is borne by the (usually white, christian, male) perpetrator alone. Violent acts of stochastic terror sit atop what the Antidefamation League call 'the pyramid of hate' while 'edgy' online memes and humour range between the second and third stage of the pyramid (Johnson, 2019a). Johnson says, "a person who commits microaggressions frequently and without any resistance from peers will become increasingly comfortable engaging in harmful, discriminatory behaviour and speech, which makes them much more likely to move up to the next tier on the pyramid" (2019a, 8:08). This internal community reinforcement coupled with strategies to diffuse ideas into the mainstream has meant that the far right has been successful in shifting the Overton Window ${ }^{8}$ of acceptable political discourse significantly (Nagle, 2017).

Johnson (2019b) proposes that to counter what he calls a 'pipeline' to the alt-right, activists will need to "[generate] effective counter-propaganda against this pipeline" (28:27) and create a "pipeline of stochastic kindness" (29:38). He says that there is a need for people speaking the language of internet culture with authenticity who can engage and de-radicalise those caught in the pipeline. There is a growing movement of Youtube content creators doing just that, employing irreverent editing and humour, creating educative entertainment (Novara Media, 2019). All visual media can be given the same treatment, and a deeper investigation of how media, such as memes, work to communicate and educate in online spaces is the next step.

rescinded his offer of a $\$ 50$,ooo donation to the Anti-Defamation League, a Jewish organisation, while wearing a shirt with an iron cross on the collar. This was construed by some as a signal to those alt-right supporters among his fans that he was 'on their side'.

8 Also known as 'the window of discourse' this is a model that describes the ideas that are acceptable to discuss in public discourse. Central on the spectrum is 'policy', spreading either side through 'popular', 'acceptable', 'radical', and 'unthinkable'. 
In the accompanying video, I have outlined how a Peircian semiotic framework might be applied to understand the powerful communicative potential of internet memes.

Image based memes with a clear form/content divide spread across participatory networks and are quickly consolidated into a habit of mind through repeated viewing. This opens up opportunities for exploitation of the medium; using it as a propaganda technique effective on the uncritical viewer, or, as Johnson (2019) outlined, as a reinforcement or verbal manifestation of undesirable attitudes. This suspension of disbelief may help to explain how memes with a clear format/content divide function to reinforce ideas. Phatic feedback loops that work to form and galvanise online communities also work to reinforce the content communicated in memes. In spaces such as 4chan or alt-right subreddits where transgression from mainstream norms is valued (Nagle, 2017), shifting further towards radical positions is rewarded as long as it is within a reasonable degree of the established position of the community.

\section{Acknowledgements}

I would like to thank Emily Parr for her assistance with videography and sound recording on this project.

\section{References}

Aharoni, T. (2019). When high and pop culture (re)mix: An inquiry into the memetic transformations of artwork. New Media \& Society. doi:10.1177/1461444819845917.

Anti-Defamation League. (2019). Murder and extremism in the United States in 2018. Retrieved from https://www.adl.org/media/12480/download.

Anti-Defamation League. (2018, May 9). How the 'OK' symbol became a popular trolling gesture. Retrieved from https://www.adl.org/blog/how-the-ok-symbolbecame-a-popular-trolling-gesture.

Anti-Defamation League. (2016). The escalation of hate. Retrieved from https://www.adl.org/sites/default/files/documents/empowering-young-peoplethe-escalation-of-hate.pdf.

Breunig, E. (2017, August 11). Why is millennial humor so weird? The Washington Post. Retrieved from https://www.washingtonpost.com. 
Brodeur, M. A. (2018, September 21). That hand symbol you're seeing everywhere? Not OK. The Boston Globe. Retrieved from https://www.bostonglobe.com.

Cannizzarro, S. \& Andersen, M. (2016) Culture as habit, habit as culture: Instinct, habituesence, addiction. In D. E. West \& M. Andersen (Eds.), Consensus on Peirce's concept of habit: Before and beyond consciousness. (pp. 314-340).

Chandler, D. (2002). Semiotics: The basics. London, United Kingdom: Routledge.

Chozick, A. (2016, September 10). Hillary Clinton calls many Trump backers "deplorables," and G.O.P. pounces. The New York Times. Retrieved from https://www.nytimes.com.

Danesi, M. (2019). Memes and the future of pop culture.

Frank, P. (2016, September 30). The strange internet journey of Pepe the 'chilled-out stoner frog'. Huffington Post. Retrieved from https://www.huffpost.com.

Johnson, E. [NonCompete]. (2019a, March 23). The PewDiePipeline: How edgy humor leads to violence [Video File]. Retrieved from https://youtu.be/pnmRYRRDbuw.

Johnson, E. [NonCompete]. (2019b, March 30). PewDiePipeline 2: How to shut it down [Video File]. Retrieved from https://youtu.be/aqRCSzUTGcM.

Katz, Y. \& Shifman, L. (2017). Making sense? The structure and meanings of digital memetic nonsense. Information, Communication \& Society, 2o(6), 825-842, doi:10.1080/1369118X.2017.1291702.

Kiberd, R. (2015, April 10). 4chan's frog meme went mainstream, so they tried to kill it. Vice Motherboard. Rerieved from https://www.vice.com.

Manovich, L. (2017). Notes on Instagrammism and mechanisms of contemporary cultural identity (and also photography, design, Kinfolk, kpop, hashtags, mise-enscène, and состояние). Retrieved from http://manovich.net/content/o4projects/og4-notes-on-instagrammism-and-mechanisms-of-contemporarycultural-identity/notes-on-instagrammism.pdf.

Metahaven. (2017). Can jokes bring down the government? Memes, design and politics. London, United Kingdom: Strelka Press.

Nagle, A. (2017). Kill all normies: Online culture wars from 4chan and tumblr to Trump and the alt-right. London, United Kingdon: Zero Books.

Nöth, W. (2016). Habits, habit change, and the habit of habit change according to Peirce. In D. E. West \& M. Andersen (Eds.), Consensus on Peirce's concept of habit : Before and beyond consciousness. (pp. 35-64).

Novara Media. (2019, May 30). Speaking in the language of YouTube | Ash Sarkar Meets ContraPoints [Video File]. Retrived from https://youtu.be/5VR4O3oHJSk.

Pelletier-Gagnon, J. \& Diniz, A. P. T. (2018). Colonizing pepe: Internet memes as cyberplaces. Space and Culture, oo(o), 1-12, doi:10.1177\%2F1206331218776188.

Phillips, W. \& Milner, R. M. (2017). Decoding memes: Barthes' punctum, feminist standpoint theory, and the political significance of \#YesAllWomen. In S.

VIDEO JOURNAL OF EDUCATION AND PEDAGOGY (2019) $\quad$ 1-9 
Harrington (Ed.), Entertainment values: How do we assess entertainment and why does it matter? (pp. 195-211) New York, NY: Springer.

Rugnetta, M. [PBS Idea Channel]. (2015, September 30). Are you literally what you post? [Video File]. Retrieved from https://youtu.be/-Ug8GZoG2qM.

Semetsky, I. (2015). Edusemiotics to date, An introduction of. In M. A. Peters (Ed.), Encyclopedia of education philosophy and theory. (pp. 703-708).

Tifentale, A. \& Manovich, L. (2018). Competitive photography and the presentation of the self. Retrieved from http://manovich.net/content/o4-projects/ogocompetitive-photography-and-the-presentation-of-theself/competitive_photography_at_lm_2016_2018.pdf.

Trump, D., Jr. [donaldtrumpjr]. (2016, September 11). A friend sent me this. Apparently I made the cut as one of the deplorables $\theta \theta \theta$ [Digital Image] Retrieved from https://www.instagram.com/p/BKMtdN 5 Bam $5 /$.

Yopak, J. (2018). The meme as a post-political communication form: A semiotic analysis. UVM Honors College Senior Theses. Retrieved from https://scholarworks.uvm.edu/hcoltheses/263. 